\title{
RELATIONAL ASPECTS BETWEEN ICT AND THE MODERNIZATION OF DIFFERENTIATED AND INDIVIDUALIZED TEACHING OF FOREIGN LANGUAGES IN HIGHER EDUCATION
}

\author{
Brânduşa-Oana NICULESCU \\ branducosma@yahoo.com \\ Georgeta OBILIŞTEANU \\ pusa_obi@hotmail.com \\ “NICOLAE BĂLCESCU” LAND FORCES ACADEMY, SIBIU, ROMANIA
}

\begin{abstract}
The amplitude of the interest and of the concerns related to the identification and the setting of the foundation necessary for perfecting higher education increasingly brings the adjustment of didactic activities to the students, particularities to the attention of educational theory and practice, with a view to forming and developing their personality.

The necessity and utilization of differentiating learning through modern methods specific to an efficient didactic methodology requires the adaptation of higher education to new modalities of organization and development, combined with knowledge adjusted to the particularities of the students' personality. The rethinking and reconsideration of the didactic activities from this perspective also benefits from the opportunities provided by the facilities of the new scientific breakthroughs in the field of technology. Therefore, making differentiated and individualized instruction efficient by using advanced technologies represents one of the challenges of updating teaching foreign languages within higher education. Being a major component, the information and communications technology (ICT) opens new and
\end{abstract}


significant opportunities, as well solutions for enhancing the level of the outcomes obtained by students in the differentiated and individualized education of foreign languages. Approaching several aspects specific to the implementation of ICT in the didactic activities pertains to the theoretical, methodological and praxiological preoccupations that aim at diversifying and increasing the obvious advantages offered by differentiated instruction in higher education.

\section{KEYWORDS: \\ Higher education, the information and communications technology, individualized and differentiated teaching, foreign languages}

\section{Introduction}

The general framework and educational policies in teaching foreign languages in higher education institutions are validated through the necessity of enhancing the quality of university education, competitivity and the professionalization of future graduates.

Through structure, objectives and content, the philological education must constantly meet the exigencies imposed by the evolution of social reality. The significances and efficiency of the didactic act are perceived and appreciated "by the availabilities of education to adapt and selfadjust to the ever more numerous defiances of the social space" (Cucoş, 2006), national and international.

The contemporary reality and, more importantly, the future reality demonstrate that the role of mastering foreign languages not only has increased, but has also become more complex due to the very influence and importance they gained in the functioning and the correlation of any segments of the social system. Having a good command of a foreign language, as well as its efficient use is a complex, multi-dimensional process demanding various academic differentiated and individualized activities.

Throughout centuries, the history of foreign language teaching has been approached in several ways which influenced the elaboration of methods and textbooks for these disciplines (Porcher, 1976). The necessity of discussing and solving the issue of valorising and developing the student's intellectual and emotional potential to the maximum emerged within this specific framework of drawing up a conception and model for learning foreign languages. This thing is possible only when the didactic activities are organized in a differentiated and individualized manner. Their efficiency proved to be greater if they are founded and sustained by a state-of-the-art technology, within which the Information and Communications Technology (ICT) represents a real, viable opportunity and solution.

To this end, beginning with 2005, the European Commission pointed to the necessity that each individual should have ICT knowledge, know foreign languages, have a technological culture, entrepreneurial spirit and interpersonal skills.

The extraordinary influence of ICT not only on learning foreign languages especially, on higher education in general, on the whole society respectively, is due to a varied assembly of factors, among which one can primarily notice that ICT represents more and more a service permanently available to people, to diverse organizations and institutions, including the higher education ones.

2. Differentiation and Individualization in Teaching Foreign Languages - Content and Pedagogical Influences 
In pedagogy, the concept of differentiation of the process of education specific to foreign languages refers to the individualized didactic activities at the level of the student, team or group of students while keeping to the unitary educational programme. Therefore, the specificity of differentiated teaching of foreign languages is represented by maintaining the curricular objectives and contents of these disciplines through the creation of educational situations pertaining to each student or micro groups of students according to their own learning intensity, aptitudes, possibilities and motivation. Thus, the creation of favourable didactic conditions that will help students to pursue their interests and penchants while achieving the common general pedagogical final objectives represents one of the pedagogical means meant to ensure genuine performance.

Differentiated instruction requires the reconsideration of some components of the didactic act: the focus is no longer on the abundance of information, but on systems of fundamental concepts, notions and principles (Hancheş, 2003). This allows for the valorisation of the potential of each student, who is regarded as a unique individuality, as well as for the identification of several personality types within students and of several teaching styles within teachers. In this way, the unity and equality in terms of the possibilities in the process of competence formation in the field of learning foreign languages involves the unity of educational finalities, the unity of the value of formation, not an identity of treatment. Differentiation refers to didactic technology, the appropriate treatment of students in the didactic activity, differentiated and individualized tasks in class and in the independent assignment, the proper presentation of knowledge respectively.

Thus, being an irrepeatable and unique individuality, the student demands individualized treatment while the creation of the learning situations will consider his possibilities and level of expectancy (Chevallard, 1985, 1991). It is necessary that individuality should be perceived as an organized, consistent whole, permanently changing while staying specific at any moment. In his theory about personality, Carl Rogers (1959) states the necessity of a closeness between the real and ideal individuality that is what the student would like to be in order to be content and motivated in what is of interest for him. Within motivation, differentiated and individualized learning resorts to and develops intrinsic motivation much more, which will ensure an increase in the interest, wish and passion for foreign languages, even in the pleasure of studying these disciplines (Postelnicu, 2003).

It is important to understand that the notion of individualized education does not necessarily involve the form of individual education, but it also refers to the organization of education (Planchard, 1992) in groups and teams. For more accuracy, the individualization according to groups or teams is called differentiated instruction nowadays and the individualization occurring within the individual organization of the process of education is called personalized instruction (Radu, 1978).

We can take into consideration the information of disciplines, the time, rhythm of study, the didactic methodology and the didactic means as modalities of differentiating and individualizing foreign language education at the level of the group, team or the student. The modalities adopted according to these possibilities also bring along changes to other aspects of the didactic activity, such as the management of this process, the teacher-student pedagogical relationship or the system of evaluation of the results obtained by the students.

However, in order to attain the desired efficiency, the normal development of the didactic activity at the level of the series or of the group of students objectively demands the blending of differentiated or individualized strategy with the collective one for the purpose of not weakening the consistency of education with the whole strength of students, that is the traditional mode, within which the differentiation and 
personalization of teaching students is attained. So, there is a direct relation and requirements specific to teaching foreign languages through the effective participation of students in the acquisition of knowledge and the model of blending the didactic activity, carried out with larger student collectivities, individualized groups or teams.

Differentiating and individualizing foreign language teaching is founded on the cognitive flexibility manifested by each student, that is his possibility of spontaneously restructuring his own knowledge in numerous and varied ways, of offering answers adapted to the situations and the demands (Spiro, Coulson, Feltovich \& Anderson, 1988) that are specific to foreign language learning.

Ensuring a balance between the individualized and the differentiated activities develops the student's capacity of becoming a participant in his own formation, the responsibility and autonomy respectively (McCombs, 2012), which will develop his ability of investigation (Balçıkanlı, 2010) for the discovery of new knowledge specific to foreign languages.

Within the higher education, there is a similitude of common general interests of students, of some intellectual capacities attaining a similar level of development, but there are also much more manifested differences in terms of their dispositions for foreign languages. Thus, against the background of the same characteristics specific to their age, there are numerous, varied and obvious individual features, differentiating them from the point of view of their aptitudes for foreign languages and, certainly, of their previous acquisitions in this matter. The same ascertainment is valid for the technical field in general, for the ICT in particular.

To this end, the quests directed to modernizing the didactic activities in order to enhance the formative capacities of foreign language differentiated and individualized learning have become more efficient with the valorisation of modern technology, within which ICT, through its component parts, produces radical changes.
We have to notice the fact that, in order to achieve differentiated and individualized learning, it is necessary that the empirical foundations and theoretical conceptions should be known, among which the ones elaborated by Skinner (1964) and Carroll (1963, 1989) are relevant. Skinner's innovative idea is that each student learns according to his own acquisition rhythm, while Carroll brings into discussion a very important variable for the understanding of learning rhythm learning time.

Based on these new innovations of didactic technology, foreign language teaching in higher education could turn from a traditional to a modern system of education, where the student's attitudes, aptitudes and knowledge can be put to good use, both in the field of linguistics, pedagogy, psychology, and that of the technology of information.

3. Opportunities of ICT in Founding the Differentiated Teaching of Foreign Languages

Contemporary pedagogy and modern didactics deal ever more often and subtly with the fundamental landmarks, allowing for turning to good account the outstanding potential provided by a new teaching strategy based on the considerable breakthroughs of science and technology. In this context, integrating ICT in the teaching-learningevaluating process of foreign languages is considered to be the implementation of a modern innovation which comprises the fields of pedagogy, didactics, technology, as well as that of organizational culture.

Having the remarkable facilities provided to education by ICT (Cucoş, 2014), nowadays we witness the emergence of new methods of foreign language differentiated instruction consisting in "reversing the pedagogy of teaching to a pedagogy of learning" (Roman, 1994).

Understanding the importance of studying foreign languages and of learning them through the opportunities provided by ICT to developing the students' personality 
and the shaping of future graduates, able to deal with the challenges of the future society, to their integrating in a global living space, profession and social integration through communication, the necessity of debating such an enterprise designated to philological education evolves. A society and a higher education system that would rather ignore these realities will come to pay the price of an unhappy choice more rapidly or later, through its visible, direct, indirect or not at all intuited or currently anticipated consequences.

The optimum valorisation of the possibilities created by ICT in the differentiated teaching of foreign languages opens new opportunities, non-existent in the past, which can certainly ensure the increase of the quality and efficiency of education in the field of these disciplines as long as this is soundly founded on the theoretical and practical scientific discoveries that have been made so far.

Due to the ICT momentum, today teachers can enjoy new, attractive modalities of presenting and utilizing the educational information in a differentiated way by integrating images, sound and animation. Enlarging the possibilities of teaching foreign languages, the students are at the same time encouraged to actively embark through personal effort on the process of their own linguistic formation.

Thus, approaching some differentiation and individualization aspects of teaching foreign languages while at the same time raising the issue of the transformations that can be brought by ICT to efficiently achieving the final objectives of the formative effort in this field will open major grounds for the theory, methodology and pedagogical, communicational-digital practicum, as well as for modern linguistics.

Not only theoreticians and the analysts of these fields are interested in this topic, but also the teaching staff. Teachers are in a continuous search for the best modalities to enhance the students' communication competences in foreign languages, understanding more and more that technology is becoming the best means of creating an environment favourable to differentiated and individualized learning. The ITC offering new technologies for obtaining information through the use of the internet, the online and offline communication methods, the e-learning programmes, the educational software for foreign languages can support teachers in making differentiated instruction of students easier, quicker, more attractive and interesting.

Therefore, in the knowledge, teacher and student triangle of axes, the student is the factor demanding more attention and revalorization. It is necessary that he should increasingly be drawn to the didactic process, which will be permanently modified in accordance with his physiological, psychological, intellectual characteristics and upon which, in his turn, he will exercise changes depending on these characteristics.

It is essential that new imperatives for the activity of foreign language teachers should be established so that teaching these disciplines might become an interactive area, an educational learning and interaction environment, based on differentiating and individualizing the didactic activities.

\section{Utilizing ICT in the} Modernization of Differentiated and Individualized Teaching of Foreign Languages

Nowadays, modern didactics places the enhancing of the interest in perfecting the organization of education at the level of higher education centre stage, as well as of the methods used in teaching disciplines, among which foreign languages play an important part. At the same time, there has evolved a concern for turning to good account the formative values of differentiating and individualizing the didactic activities that benefit from the special facilities provided by ICT.

Representing the path the students prefer for study, ICT has become quite an important, integrated part of their world. They play, have fun, solve certain problems, study and communicate a lot by using it. 
They tend to be the beneficiaries of a more visual training than the previous generations since their world is rich in visual simulation. So, ICT matches with what is known about the way young people prefer to study, train and, certainly, communicate. In this way, the use of the technology will highlight the unique human qualities of each student in a more varied and poignant manner, while the students will become more human.

As an educative didactic technology, the use of ICT in teaching foreign languages makes room for interactivity, regarded as "the capacity of response of the ordinator (and of his software) to the user's actions, his capacity of retro action or feedback" (Naymark, 1998).

However, in order to achieve this, each teacher should ensure the integration

of ICT by establishing priorities in the use of appropriate educational software when the higher education institution is equipped with corresponding hardware and software components. The computer is animated by the software being used, which should support the student in discovering new information in a differentiated and individualized way, in clarifying it and in successfully using it.

In fact, the educational software represents today "the most important technological breakthrough of modern pedagogy" (Mârşanu, 2010). But it is equally important to understand that, as an ICT informational product, the educational software does not decisively influence the modification of the content of the foreign language teaching process. Used at the individual or group level, this diversifies the didactic activity, changes the teacher's and the student's role, doing a service to the latter in his acquisition of theoretical and practical mastery of foreign languages.

In its turn, the internet becomes a functional and efficient instrument that can reunite many possibilities of achieving differentiation and individualization in the teaching, learning and evaluation of foreign languages. Using the internet in class with maximum efficiency creates the possibility of carrying out several projects, learning and evaluation tasks by each student, even initiated and conducted by the student. Thus, learning is differentiated and individualized, not standardized.

The utilization of the pedagogical model based on projects can ensure the paradigm change through differentiated and individualized teaching of foreign languages. Promoting genuine investigation and demonstrations of learning through efficient results, the project method is oriented towards essential questions of the curriculum, making the connection between the quality standards of the educational final objectives, the higher cognitive capacities of the student and the real-life situations. For instance, a project that the students may have to complete can demand the analysis of a literary work and the identification of the typology of characters, afterwards enabling them to compare different characters in conformity with their own option, at the end of a period of readings and of consulting bibliographical sources. On the way, the students are questioned and guided so that they might correctly sort out the educational task consisting in the presentation of an essay, a summary or a 3 to 5 page synthesis, representing the outcome obtained throughout the completion of the respective project.

Not only the quality of the project being assessed, but also the way in which the student managed its development, he will understand that, if he is to attain high performance, he has to know how to selfmanage, how to organize the technique of intellectual work and other activities, as well as be aware of the necessity to meet the exigencies of achieving an individual learning task. Evaluation, including other modalities such as solving items or tests by means of ICT, removes the student's anxiety and fear by turning his attention from the most often blank sheet of paper to the mode of delivering the content of evaluation (Ministry of Communications and Informational Society, 2009).

Interpersonal communication achieved by means of e-mail, direct communication 
(chatting), the use of online platforms on an ever larger scale, of web cameras, microphones, of blogging or of the forum, all of these complete the facilities provided by ICT for the differentiation of the didactic activities and for the individualization of the student's participation in the process of formation of the competences pertaining to the field of foreign languages.

Through its hard and software components, the calculator as a single technical means, as well as accompanied by other ICT devices, such as the video camera, the power point presentations, videos, online dictionaries and encyclopaedias, interactive books and whiteboards, websites, etc., brings ingenious, innovative solutions to achieving the desired results of differentiated instruction, as well as permanent challenges for the didactic activities designated for learning foreign languages.

\section{Conclusions}

The analysis of the relation between ICT and differentiated and individualized teaching of foreign languages in higher education demonstrates that this technology is not only a support or an auxiliary means for the didactic activities, but also an indispensable component of them. What characterizes ICT is the co-existence on the same support of technologies, of the letter, image, sound components and the ensurance of access to information as long as these are reunited in a differentiated and individualized, modern and efficient activity.

ICT reconfigures the place of teaching foreign languages, the teacher-student relation being modified. In this way, the student and teacher interactively participate in the discovery of knowledge and the implementation of differentiated pedagogy requirements, supported by ICT, contributes to the mobilization of individual knowledge and skills for the formation of each student's foreign language communication competences. Thus, the ICT potential encourages the innovation of foreign language differentiated and individualized teaching and becomes an essential solution to efficiently responding to the challenges of the modern environment of academic education.

\section{REFERENCES}

Balçıkanlı, C. (2010). Learner Autonomy in Language Learning: Student Teachers' Beliefs. Australian Journal of Teacher Education, 35(1), pp. 90-103, Retrieved from http://dx.doi.org/10.14221/ajte.2010v35n1.8

Carroll, J.B. (1963). A model of school learning. Teachers College Record, 64, pp. 723-733.

Carroll, J.B. (1989). The Carroll Model: A 25-Year Retrospective and Prospective View, Educational Researcher, 18(1), pp. 26-31. Retrieved from doi: 10.3102/ 0013189X018001026

Chevallard, Y. (1985). La Transposition didactique: du savoir savant au savoir enseigné (2ème édition augmentée 1991), Grenoble: La Pensée Sauvage, Apud. Cucoş, C. (2014). Pedagogie, ediţia a III-a revăzută şi adăugită. Iaşi: Polirom, p. 406.

Cucoş, C. (2006). Pedagogie, ediţia a II-a revăzută şi adăugită. Iaşi: Polirom, p. 50.

Cucoş, C. (2014). Pedagogie, ediţia a III-a revăzută şi adăugită. Iaşi: Polirom, p. 89.

Hancheş, L. (2003). Instruirea diferenţiată. Aspecte moderne în elaborarea strategiilor didactice. Timişoara: Eurostampa, p. 86.

Mârşanu, R. (2010). Calculatoarele şi sistemul educaţional. Tribuna Economică, secţiunea Informatică, 39, pp. 24-26. Retrieved from http://www.tribunaeconomica.ro/ index.php?id_tip_categorie $=1 \&$ id_categ $=90 \& i d \_r e v i s t a=9512 \& i d \_n r \_r e v i s t a=253 \&$ mode $=$ revista

McCombs, B. (2012). Developing responsible and autonomous learners: A key to motivating students. Retrieved from: http://www.apa.org/education/k12/learners.aspx 
Ministerul Comunicaţiilor şi Societăţii Informaţionale. (2009). Proiectul Economia Bazată pe Cunoaştere. Cursul Utilizarea calculatorului personal: aplicarea TIC în şcoală şi afaceri. Modulul 8 "Aplicarea TIC în şcoală", 40. Retrieved from: http://www.ecomunitate.ro/upload/instruire/pdf/Modul\%208\%20School\%20Development.pdf

Naymark, J. (1998). Multimédia et formation. Paris: Éditions Retz, p. 13.

Planchard, E. (1992). Pedagogie şcolară contemporană. Bucureşti: EDP, pp. 238-239.

Porcher, L. (1976). Qui progresse vers quoi? In ELA: La notion de progression en didactique des langues, 16, Paris: Didier Erudition, p. 53.

Postelnicu, C. (2003). Fundamente ale didacticii şcolare. Bucureşti: Aramis, p. 292.

Rogers, C.R. (1959). A theory of theraphy, personality, and interpersonal relationships, as developed in the client-centered framework. In S. Koch (Ed.), Psychology: A Study of a Science. Study 1, Volume 3: Formulations of the Person and the Social Context. New York, NY: McGraw-Hill, 184-256. Retrieved from: https://drive.google.com/file/d/0B3a1o9R47k WNeGtXemhGbXAxM3c/view

Roman, D. (1994). La didactique du français langue étrangère. Baia Mare: Umbria, pp. 23-91.

Skinner, B.F. (1964). New methods and new aims in teaching, New Scientist, 122, pp. 483-484.

Spiro, R.J., Coulson, R. L., Feltovich, P.J., Anderson, D.K. (1988). Cognitive flexibility theory: Advanced knowledge acquisition in ill-structured domains. In V. Patel (Ed.), Proceedings of the $10^{\text {th }}$ Annual Conference of the Cognitive Science Society. Hillsdale, NJ: Erlbaum, pp. 640-653. Reprinted in D.E. Alvermann, N.J. Unrau, R.B. Ruddell (Eds.). (1994). Theoretical Models and Processes of Reading ( $6^{\text {th }}$ edition). Newark, DE: International Reading Association, 544-557. Retrieved from: doi: 10.1598/0710.22. 